\title{
PRELIMINARY CHARACTERIZATION OF BRITTLE DEFORMATION ON THE INISKIN PENINSULA: IMPLICATIONS FOR THE KINEMATIC HISTORY OF THE BRUIN BAY FAULT SYSTEM, LOWER COOK INLET, ALASKA
}

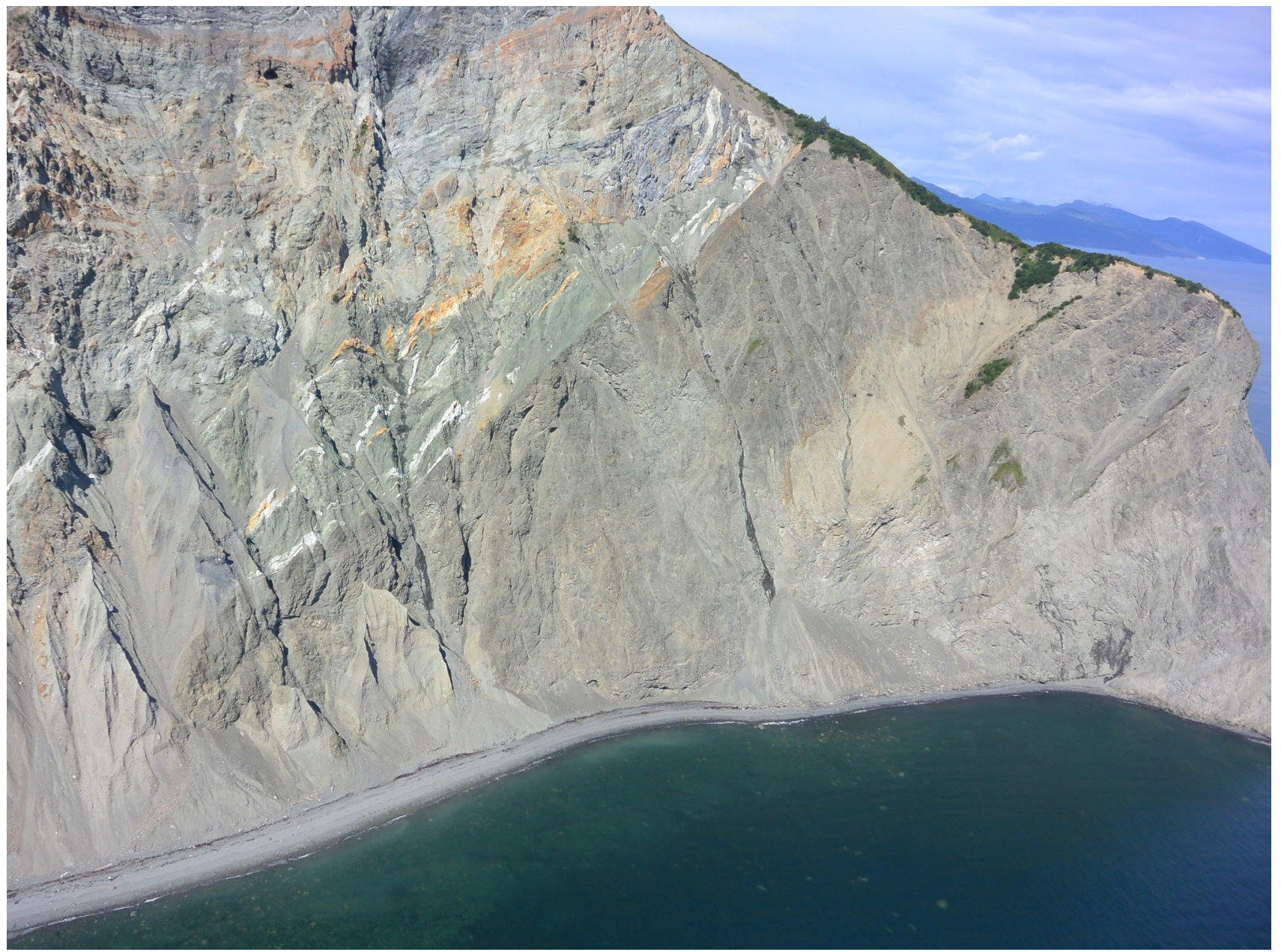

Aerial view northeastward of the Bruin Bay fault at Uras's Head, Cook Inlet. Here, Triassic-Lower Jurassic carbonate and volcanic rocks of the Kamishak Formation are thrust above Upper Jurassic clastic rocks (Naknek Formation) of the Cook Inlet forearc basin. Background: Southeastward-dipping strata of the Naknek Formation in the footwall of the Bruin Bay fault on the Iniskin Peninsula.

October 2014

Released by

STATE OF ALASKA

DEPARTMENT OF NATURAL RESOURCES

Division of Geological \& Geophysical Surveys 



\section{CONTENTS}

Introduction. .1

Geologic background: The Bruin Bay fault and the Iniskin Peninsula................................................................

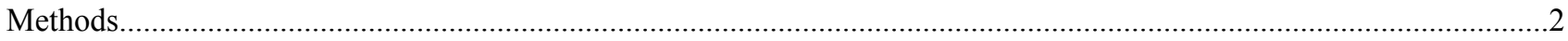

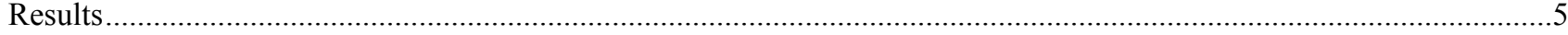

Faults that record southeast-trending subhorizontal shortening, population A ...................................................5

Faults that record east-trending subhorizontal shortening, population B.....................................................

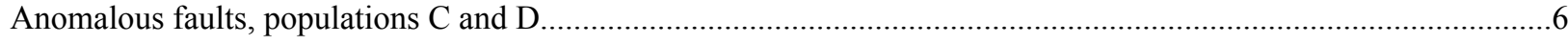

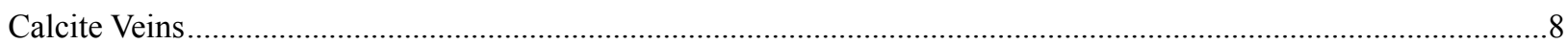

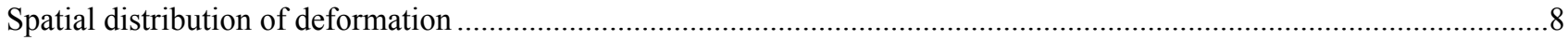

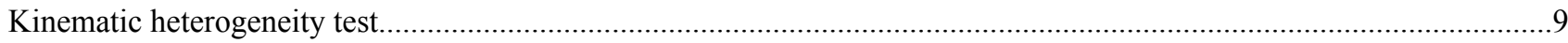

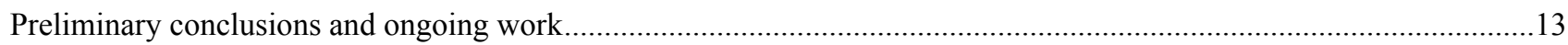

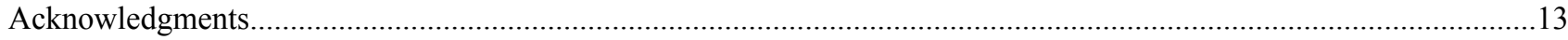

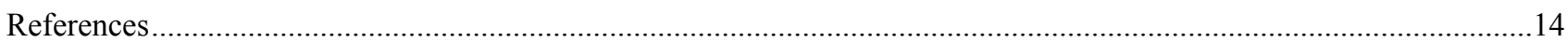

\section{FIGURES}

Figure 1. Simplified tectonic map of southern Alaska, showing major tectonic elements and location of the

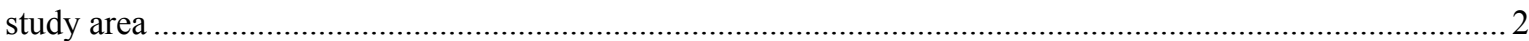

2. Simplified geologic map of the Iniskin Peninsula, showing major structures and stratigraphic units ............. 3

3. Photographs of fault zones in the Kamishak and Talkeetna Formations in the northwestern part of the map area, and a stereogram showing an example fault plane .............................................................. 4

4. Stereograms showing fault kinematic results from all reverse, right- and left-lateral faults with southeasttrending shortening axes

5. Stereograms showing fault kinematic results from all left-lateral and right-lateral faults with east-trending shortening axes.

6. Stereograms showing fault kinematic results for all oblique-slip and normal faults with anomalous shortening axes.

7. Stereogram and rose diagram showing attitudes and strike distributions of the total population of veins in this study

8. Simplified geologic map of the Iniskin Peninsula, showing spatial distribution of faults with southeastand east-trending shortening axes

9. Stereograms showing shortening axes, extension axes, and poles to fault planes from all faults in populations $\mathrm{A}$ and $\mathrm{B}$ 



\section{PRELIMINARY CHARACTERIZATION OF BRITTLE DEFORMATION ON THE INISKIN PENINSULA: IMPLICATIONS FOR THE KINEMATIC HISTORY OF THE BRUIN BAY FAULT SYSTEM, LOWER COOK INLET, ALASKA}

by

Paul M. Betka ${ }^{1}$ and Robert J. Gillis ${ }^{1}$

\section{INTRODUCTION}

An ongoing program by the Alaska Division of Geological \& Geophysical Surveys aims to understand the Mesozoic and Cenozoic geologic evolution of the northwestern margin of the Cook Inlet forearc basin. This study is directed at understanding the kinematic evolution, relative timing, and tectonic significance of brittle deformation that occurred on the Iniskin Peninsula, Cook Inlet, Alaska. The Iniskin Peninsula is transected by the Bruin Bay fault system, a major northeaststriking structural boundary in southeastern Alaska that is continuous for $>450 \mathrm{~km}$ from the upper Alaska Peninsula to the northwest terminus of Cook Inlet (fig. 1). The Bruin Bay fault system defines the tectonic boundary between Mesozoic and Cenozoic sediments of the Cook Inlet forearc basin to the southeast and the crystalline intrusive suite and volcanic edifice of the Jurassic Talkeetna arc toward the northwest for most of its exposed length. Provenance studies of adjacent Jurassic-Tertiary forearc basin strata suggest that the Bruin Bay fault system accommodated a component of reverse motion during the Jurassic that resulted in the exhumation and denudation of the volcanic arc in its hanging wall and syntectonic sedimentation in the Cook Inlet forearc basin in the footwall (LePain and others, 2011; Wartes and others, 2013; compare with Trop and others, 2005). However, despite its large geographic extent and potential significance as a major tectonic boundary in southeastern Alaska, relatively little is known about the kinematic history of the Bruin Bay fault system.

In this report, we present field observations and kinematic analyses from 125 fault surfaces that are exposed in both the hanging wall and footwall of the Bruin Bay fault system. The data are interpreted to describe bulk kinematics of deformation in the Bruin Bay fault system, discern kinematically compatible fault populations, and test for potential genetic relationships between different sets of faults. Results indicate that 86 percent of the faults measured belong to one of two kinematically distinct populations of faults $(\mathrm{n}=56$ and $\mathrm{n}=52$ ), and they are discussed with the goal of understanding the Mesozoic to Cenozoic kinematic history of the Bruin Bay fault system in southeastern Alaska. Ongoing work in 2014 will result in a more complete report in the following year.

\section{GEOLOGIC BACKGROUND: THE BRUIN BAY FAULT AND THE INISKIN PENINSULA}

Detterman and Hartsock (1966) published the first map of the Bruin Bay fault on the Iniskin Peninsula. Here, the fault separates Lower-Middle Jurassic volcanic, volcaniclastic, and intrusive rocks of the Talkeetna Formation and Triassic marbles (Kamishak Formation? age uncertain) in its hanging wall from Middle to Upper Jurassic synorogenic marine forearc strata in its footwall. These authors also mapped a system of steeply-dipping northeast-striking faults that occur in the hanging wall of the Bruin Bay fault and locally juxtapose Jurassic volcanic and volcaniclastic deposits of the Talkeetna Formation and Triassic carbonate rocks of the Kamishak Formation (Detterman and Hartsock, 1966). Detterman and Reed (1980) postulated that the steeply-dipping faults are part of the Bruin Bay fault system and suggested a genetic relationship among all of the faults in the hanging wall with the Bruin Bay fault. Detterman and Hartsock (1966) and Detterman and Reed (1980) interpreted that the fault system accommodated $19-65 \mathrm{~km}$ of sinistral displacement on the basis of poorly constrained stratigraphic piercing points. Despite early attempts to understand the kinematic history of the fault system, the sense of slip, relative timing, and tectonic significance of individual faults gleaned from map patterns remains ambiguous.

Reconnaissance work by Gillis and others (2013), which focused on a well-exposed segment of the Bruin Bay fault system southwest of the Iniskin Peninsula, indicated a component of top-southeast reverse motion along a northwest-dipping $\left(40-50^{\circ}\right)$ fault plane. On the Iniskin Peninsula in the footwall of the fault, Middle and Upper Jurassic strata of the Tuxedni, Chinitna, and Naknek Formations are folded by upright, open folds that trend northeast and form a regional syncline-anticline pair with wavelengths $\sim 1-2 \mathrm{~km}$. The folds occur between overlapping, right-stepping segments of the Bruin Bay fault system including the Bruin Bay and Fitz Creek faults that have top-southeast reverse offset (fig. 2). Regional map patterns indicate that the folds plunge shallowly southwest and northeast and that they decrease in amplitude downplunge.

${ }^{1}$ Alaska Division of Geological \& Geophysical Surveys, 3354 College Rd., Fairbanks, Alaska 99709-3707; paul.betka@alaska.gov; robert.gillis@alaska.gov 
Hence, local folding of Jurassic strata in the footwall of the Bruin Bay fault occurs in a right-stepping segment of the Bruin Bay fault system (fig. 2). New mapping conducted by the Alaska Division of Geological \& Geophysical Surveys (Gillis and others, 2014) revealed several other map-scale faults that occur on the Iniskin Peninsula that are both subparallel and oblique to the main segments of the Bruin Bay fault system (fig. 2). To better determine the distribution, kinematic history, and tectonic significance of brittle deformation with respect to the Bruin Bay fault system, we present a new fault kinematic dataset of 125 faults from the Iniskin Peninsula.

\section{METHODS}

A population of fault-slip data $(n=125)$ was collected by measuring the attitudes of fault surfaces and associated slip lineations. The sense of shear on individual faults was determined using kinematic indicators including Riedel shears, fault surface asperities, preferred orientations of associated tensile or sigmoidal veins, and other common methods (for example,

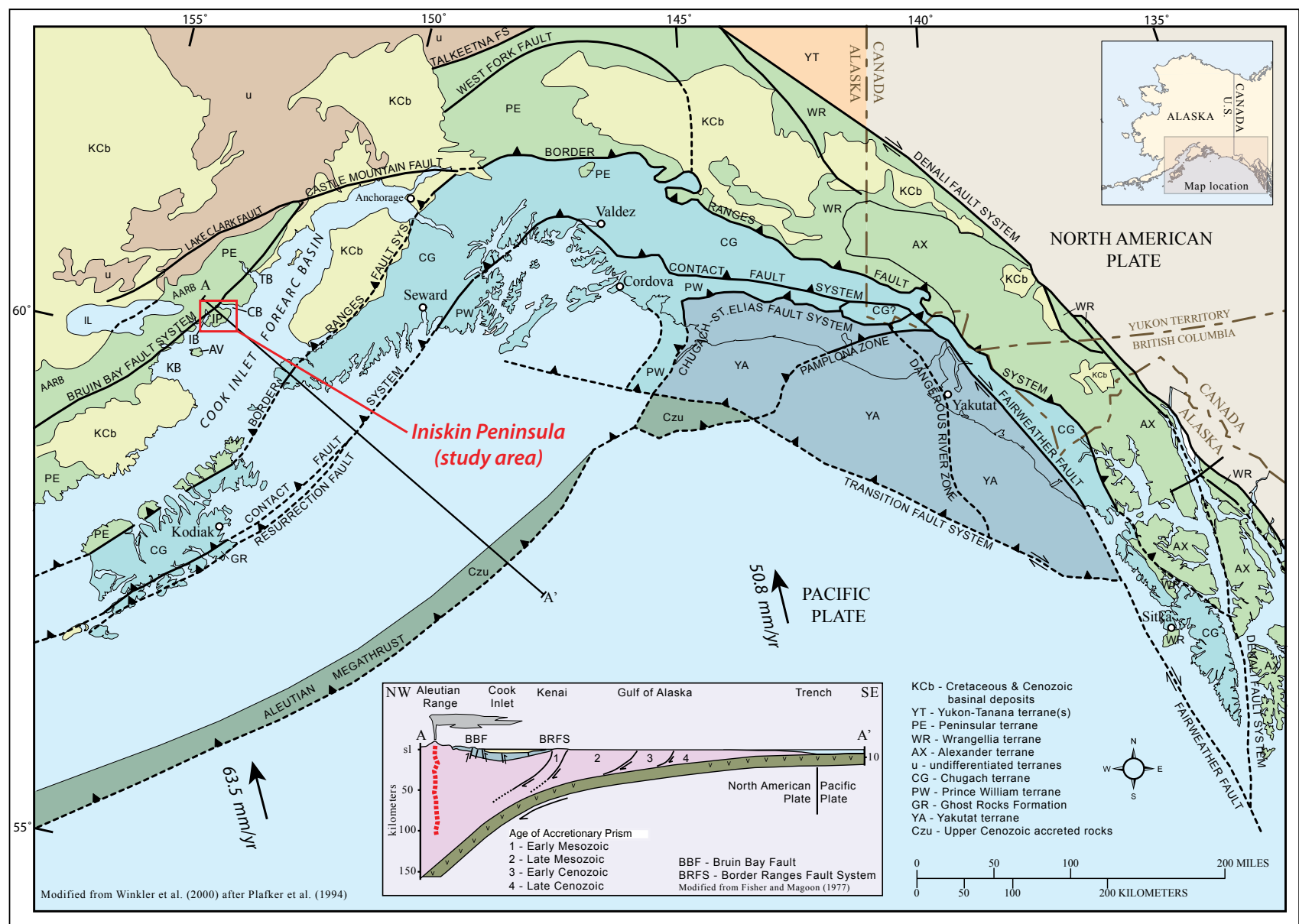

Figure 1. Simplified tectonic map of southern Alaska, showing major tectonic elements and location of the study area. Modified from Winkler and others (2000). Inset cross-section modified from Fisher and Magoon (1977). Key to abbreviations not defined on map: AARB -Aleutian-Alaska Range Batholith; AV-Augustine volcano; CB-Chinitna Bay; IL_Iliamna Lake; IB-Iniskin Bay; IP-Iniskin Peninsula; KB-Kamishak Bay; TB-Tuxedni Bay.

Figure 2 (right). A. Simplified geologic map of the Iniskin Peninsula, showing major structures and stratigraphic units. Modified after an unpublished draft geologic map of the Iniskin Peninsula that is part of an ongoing campaign by the Alaska Division of Geological \& Geophysical Surveys. Extent of Quaternary cover (Q) after Detterman and Harsock (1966). BBF-Bruin Bay fault segment; FCF-Fitz Creek fault segment. Inset in lower right shows the study area on a simplified geologic map of the Iniskin region. B. Equal-area lower-hemisphere stereographic projection showing poles to bedding. Kamb contour intervals are 2 sigma. Great circle is a cylindrical best fit to data; star is the regional fold axis $\left(221^{\circ} / 01^{\circ}\right)$ as determined from the cylindrical best fit (i.e., the $\pi$-axis). All stereograms hereafter are equal-area lower-hemisphere projections. 


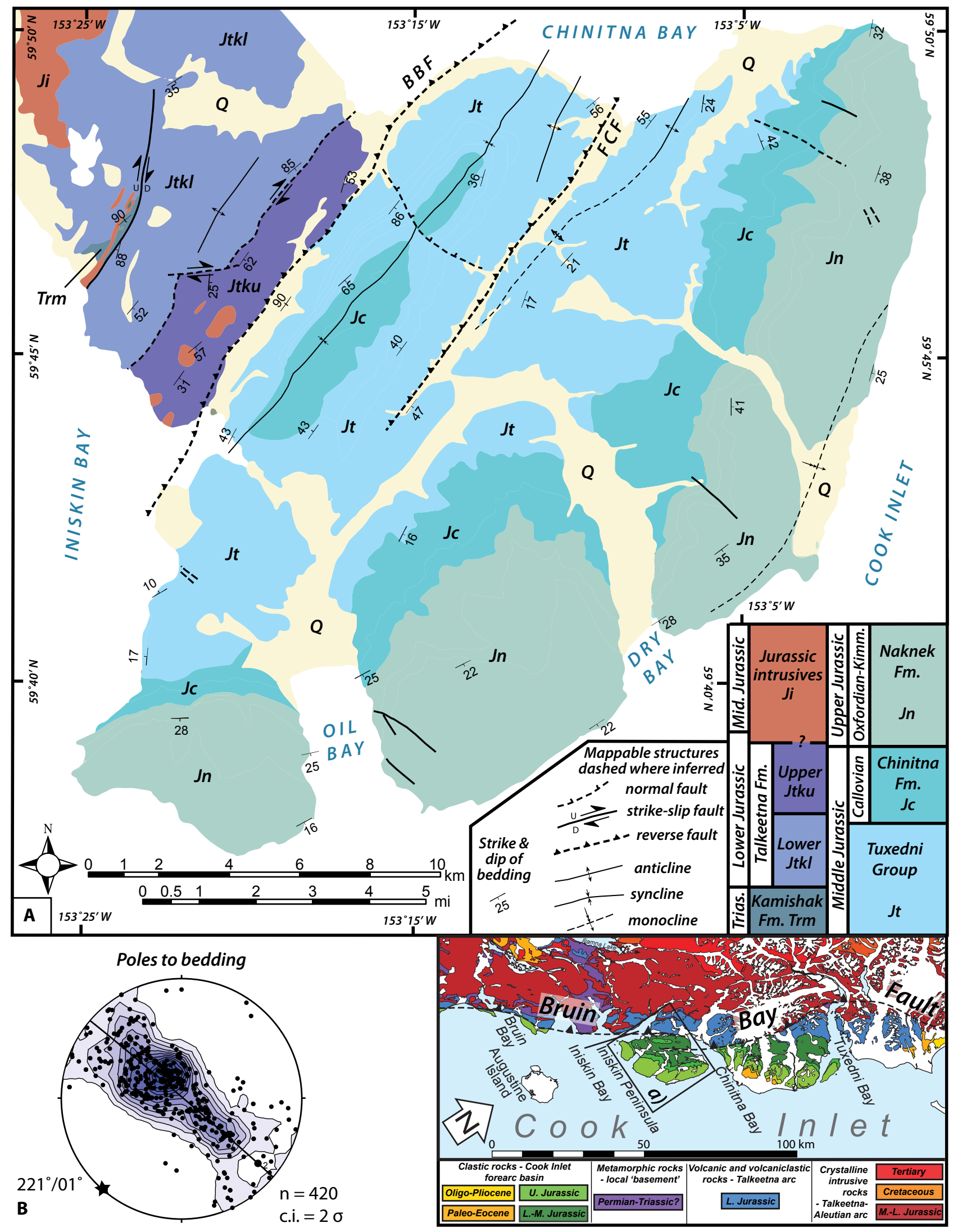



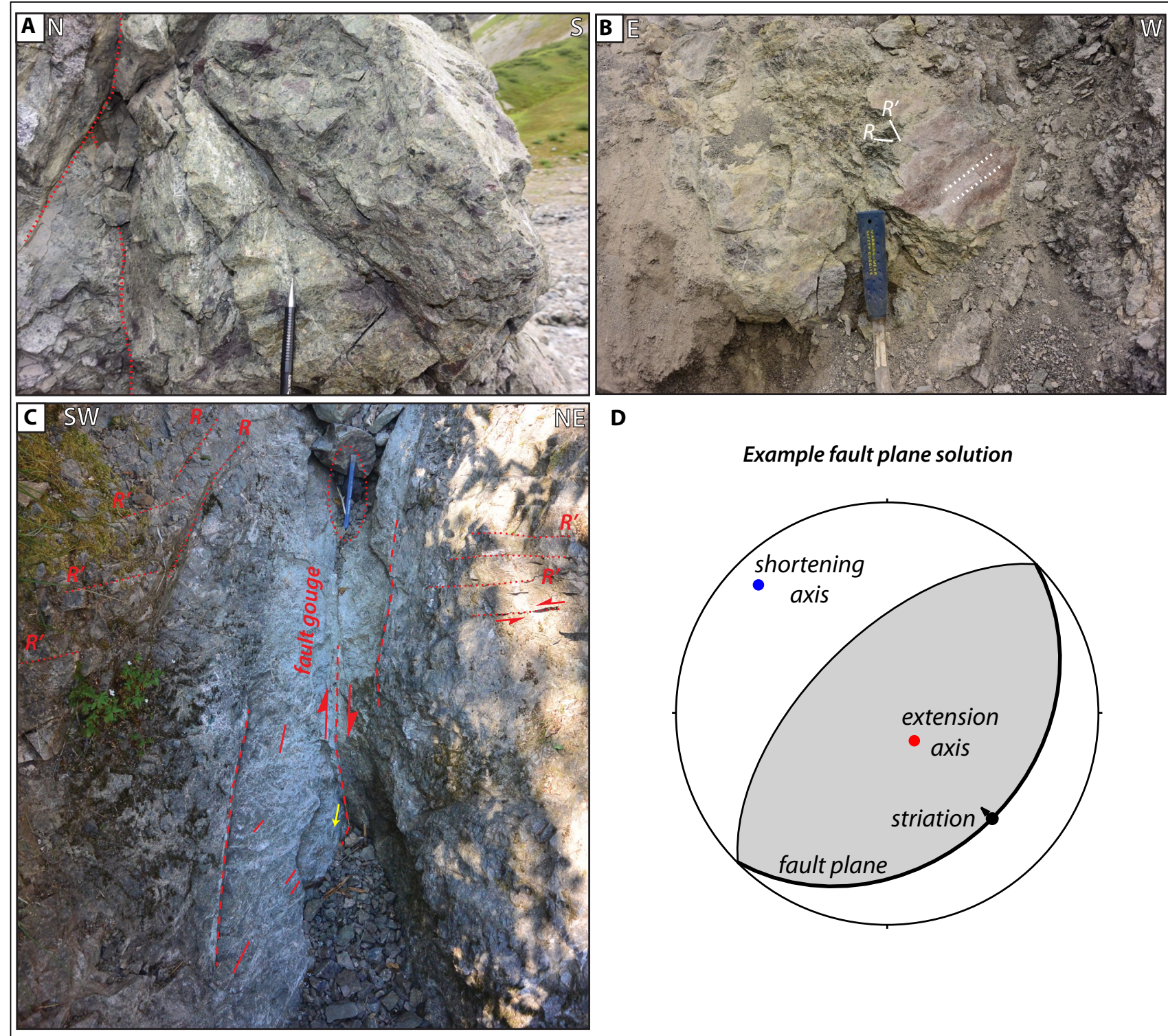

D

\section{Example fault plane solution}

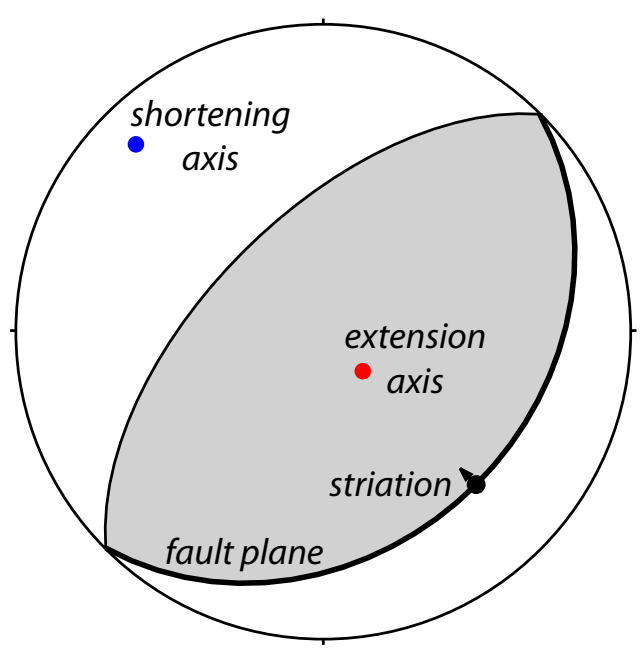

Figure 3. A. Photograph of a fault zone that contains marble cataclasite and defines the contact between the Kamishak and Talkeetna Formations in the northwestern part of the map area (see fig. 2). Two fault surfaces are highlighted with broken lines, however, several other fault surfaces occur in the photograph. Pencil for scale. B. Photograph of a striated slip surface in the fault zone from A. Striations are highlighted with broken lines; solid lines show the orientations of Riedel shears that were used to interpret the sense of slip (right-lateral). Crack hammer handle for scale. C. Photograph of a fault zone that cross-cuts the upper member of the Talkeetna Formation. Fault zone boundaries are highlighted with heavy dashed lines. Thin dashed lines show the orientations of Riedel shears. Short solid lines in the fault zone are parallel to tensile calcite veins. The yellow arrow on the fault surface is parallel to the striation and shows the plunge direction. Chisel for scale (dotted oval). This fault records right-reverse oblique motion. D. Stereogram showing an example fault plane solution. The fault plane (heavy great circle), kinematic axes, and striation are labeled. Arrowhead on the striation shows the sense of motion of the hanging wall (top-northwest). The gray and white shading represents extension and shortening dihedra, respectively. Modified after Marrett and Allmendinger (1990). 
Petit, 1987; figs. 3A-C). The quality of shear-sense indicators was ranked for each fault and considered when interpreting the dataset.

To interpret the population of fault-slip data, we followed the methods of Marrett and Allmendinger (1990); we present a graphical comparison of the distribution and orientations of average incremental strain axes between subsets of faults. This method assumes that kinematically compatible, scale-invariant faults should form subsets that are defined by subparallel kinematic (shortening and extension) axes. Kinematic axes occur in the plane defined by the slip lineation and pole to the fault plane (movement plane) and bisect the angle between them; the sense of slip determines the shortening and extension axes (fig. 3D; Marrett and Allmendinger, 1990). The faults are assumed to be kinematically scale-invariant, an assumption that is supported by both natural (for example, Marrett and Allmendinger, 1992) and theoretical (for example, Turcotte, 1986) examples of fault populations and is qualitatively supported by kinematically compatible fault populations in this study with gouge thicknesses that span four orders of magnitude $\left(10^{-3}-10^{1} \mathrm{~m}\right)$. Although the fault population consists of individual discrete slip surfaces, map-scale faults in the population area are weighted by a sampling bias because they were measured several times in different locations.

Subsets of the total population $(n=125)$ were delineated using the attitude(s) of the kinematic axes, sense of slip and/ or attitude of the fault plane, and/or rake of the striation such that each subset consists of dip-slip or strike-slip faults with mutually subparallel kinematic axes. Directional maxima for clusters of shortening and extension axes of each subset were calculated using the linked Bingham statistics of FaultKin (Allmendinger and others, 2012; Marrett and Allmendinger, 1990). Small circles that represent 95 percent confidence cones around directional maxima were calculated separately for shortening axes using the Bingham axial distribution function of Stereonet (Allmendinger and others, 2013; Cardozo and Allmendinger, 2013). In all cases, the directional maxima of shortening axes calculated by the linked Bingham method were within the 95 percent error margin of those determined using the Bingham axial distribution (discussed below). Thus, the authors interpret the linked Bingham axes to reflect statistically significant orientations of the average incremental strain axes for each subset of faults. To qualitatively understand the degree of spatial homogeneity of fault kinematics, data from each subset were plotted separately on the geologic map at their sampling localities and compared.

\section{RESULTS}

The total population of faults $(n=125)$ was divided into kinematically distinct groups on the basis of the attitude, type of fault, sense of shear, and orientation of kinematic axes. We defined seven subsets of faults that form four kinematically compatible groups. The subsets include one set of reverse faults, five unique sets of strike-slip faults, and one set of normal faults. The reverse faults and two sets of strike-slip faults form a group of faults $(\mathrm{n}=56)$ that record southeast-trending subhorizontal shortening, hereafter referred to as population A (fig. 4). Two additional sets of strike-slip faults together define a group $(n=52)$ that records east-trending subhorizontal shortening that we refer to as population B (fig. 5). A third set of strike-slip faults (population $\mathrm{C}, \mathrm{n}=12$ ) and a separate set of normal faults (population $\mathrm{D}, \mathrm{n}=5$ ) each form a small subset of faults with anomalous kinematics that do not belong to either of the dominant fault groups (fig. 6). Of the total population, 86 percent $(n=108)$ of the faults belong to either population A or B (figs. 4 and 5). Each fault set is discussed in detail below.

\section{Faults that record southeast-trending subhorizontal shortening, population A}

Reverse faults in the study area $(n=23)$ strike northeast and dominantly dip steeply to gently southeast. Striae on reverse fault surfaces have rakes between $50^{\circ}$ and $90^{\circ}$. Shortening axes for reverse faults plunge shallowly southeast or northwest. Extension axes plunge steeply. The trend and plunge of the mean shortening axis for reverse faults determined by the linked Bingham method is $134^{\circ} / 13^{\circ}$ and for the mean extension axis is $317^{\circ} / 77^{\circ}$. The intermediate strain axis is subhorizontal and trends $224^{\circ}$ (fig. 4A).

Strike-slip faults that record southeast-trending subhorizontal shortening form a subset $(\mathrm{n}=33)$ that consists of northnortheast-striking left-lateral faults and west-northwest-striking right-lateral faults (fig. 4B). Both left- and right-lateral faults dip steeply. Striations on fault surfaces rake between $0^{\circ}$ and $54^{\circ}$. Shortening axes plunge shallowly northwest and southeast. Extension axes plunge shallowly northeast and southwest. The average shortening axis calculated by the linked Bingham method plunges $18^{\circ}$ toward $151^{\circ}$. The average extension axis trends $242^{\circ}$ and plunges $4^{\circ}$. The intermediate strain axis is subvertical (fig. 4B). Both subsets of strike-slip faults and the subset of reverse faults have subparallel shortening axes and thus define a kinematically compatible population $(n=56)$ that records southeast-trending shortening (fig. 4 C). Linked Bingham statistics indicate that trend and plunge of the mean shortening axes for the population is $147^{\circ} / 16^{\circ}$. The trend and plunge of the mean extension axis is $240^{\circ} / 12^{\circ}$. The Bingham axial distribution of shortening axes indicates the trend and plunge of the mean axis is $145^{\circ} / 16^{\circ} \pm 7^{\circ}$ (fig. $4 \mathrm{C}$ ). 


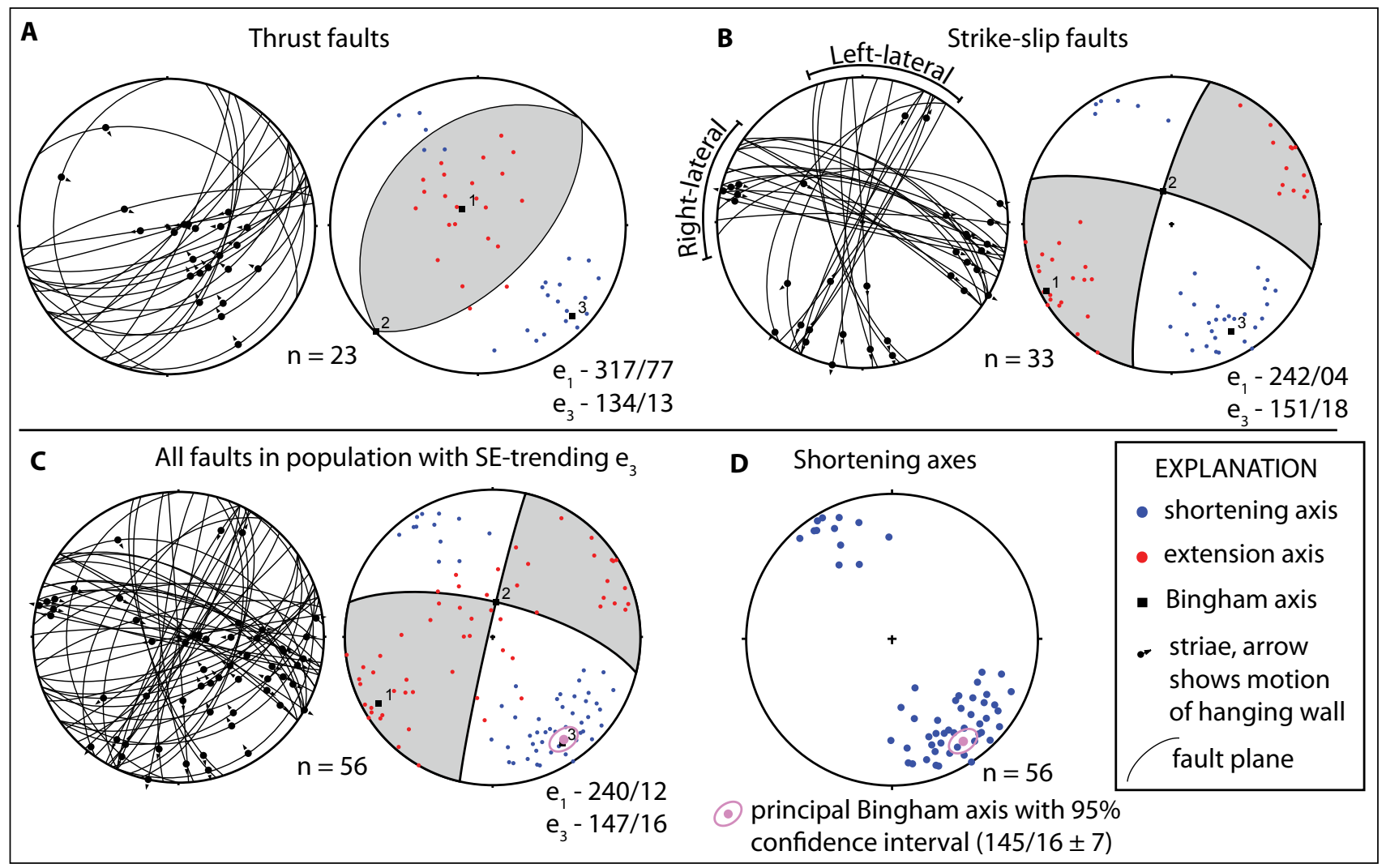

Figure 4. Stereograms showing fault kinematic results from all reverse (A), right- and left-lateral (B) faults with southeast-trending shortening axes (population A). C. Combined results from both $A$ and $B$. The left-hand plot in A-C shows the attitudes of faults and striae; the right-hand plot shows kinematic axes, linked Bingham axes (1, extension; 2, intermediate; 3, shortening), and shortening and extension dihedra. See text and figure 3D for explanation. Trend and plunge of linked Bingham axes are listed (e1, extension; e3, shortening). D. Stereogram of shortening axes from C; solid lavender circle and surrounding small circle show the directional maxima and 95 percent confidence interval, respectively, for shortening axes only. Note that the linked Bingham shortening axis (e3) in $C$ is subparallel to the mean shortening axis in D and within the 95 percent confidence interval.

\section{Faults that record east-trending subhorizontal shortening, population B}

A second group of strike-slip faults that records east-trending subhorizontal shortening consists of northwest-striking left-lateral faults $(\mathrm{n}=24)$ and northeast-striking right-lateral faults $(\mathrm{n}=28$; figs. 5A, B). Both left- and right-lateral fault surfaces dip steeply and contain mostly shallowly-plunging striae that rake between $0^{\circ}$ and $54^{\circ}$. Shortening axes from both right- and left-lateral sets plunge shallowly east and west. Extension axes plunge shallowly north and south. Linked Bingham statistics for left-lateral faults indicate the trend and plunge of the average shortening axis is $093^{\circ} / 08^{\circ}$ and the extension axis is $184^{\circ} / 07^{\circ}$. The intermediate strain axis is subvertical (fig. 5A). Similarly, right-lateral faults have a horizontal linked Bingham shortening axis that trends $274^{\circ}$ and an extension axis that is oriented $183^{\circ} / 04^{\circ}$ (fig. 5B). Right- and left-lateral faults have mutually subparallel kinematic axes and thus define a single kinematically distinct subset (population B, $\mathrm{n}=52$ ) of strike-slip faults defined by shallowly east- and west-plunging shortening axes (fig. 5C). Linked Bingham statistics for the entire subset $(\mathrm{n}=52)$ indicate the mean shortening axis trends $093^{\circ}$ and plunges $03^{\circ}$ and the mean extension axis trends $186^{\circ}$ and plunges $05^{\circ}$ (fig. 5C). A Bingham axial distribution of the shortening axes indicates an average shortening direction of $094^{\circ} / 32^{\circ} \pm 9^{\circ}$ (fig. 5D).

\section{Anomalous faults, populations C and D}

A small subset $(n=12)$ of oblique-slip faults have shortening axes that plunge shallowly southwest (population C, fig. 6A). In this subset, fault surfaces strike northwest and dip steeply southwest. Striae plunge moderately to steeply southeast and kinematic indicators record oblique, right-normal or right-reverse sense of slip depending on the dip direction of the fault. One fault strikes northwest and contains a steeply-plunging northwest-trending striation and records reverse-left sense of slip. Shortening axes plunge moderately toward the southwest and linked Bingham statistics indicate the mean shortening axis 

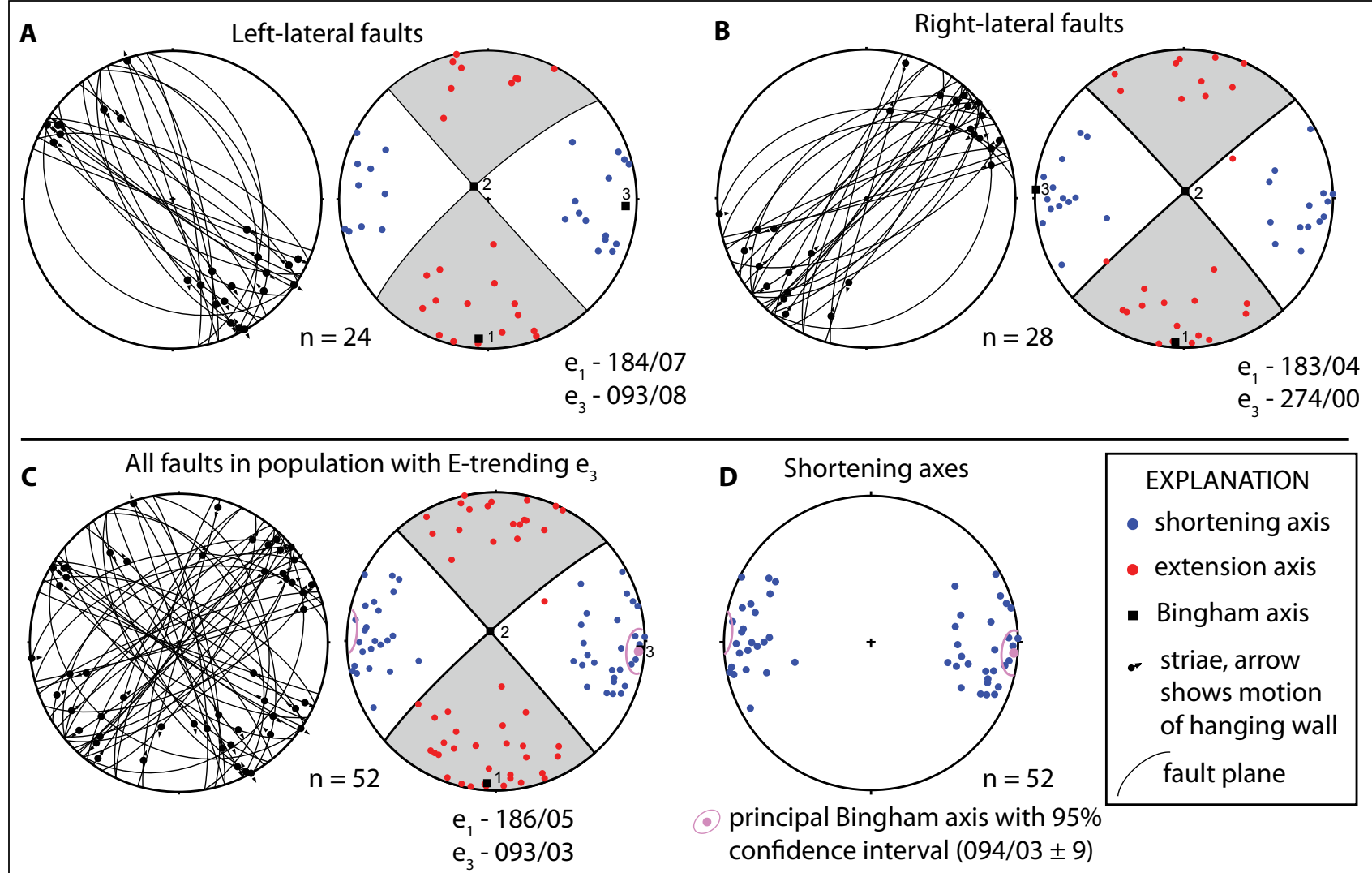

Figure 5. Stereograms showing fault kinematic results from all left-lateral (A) and right-lateral (B) faults with east-trending shortening axes (population B). C. Combined results from both A and B. D. Shortening axes showing mean and 95 percent confidence interval. Stereograms and data are presented as described in the caption of figure 4.

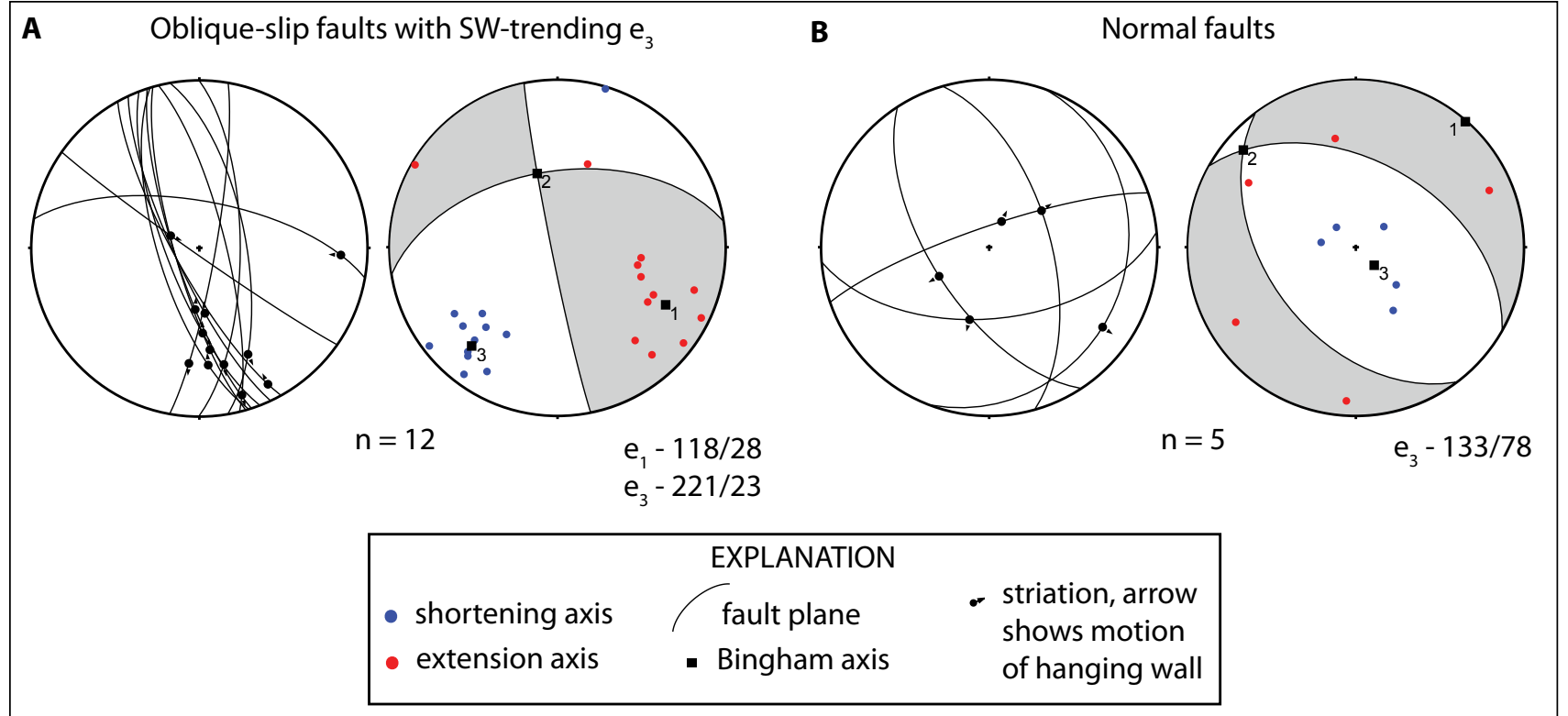

Figure 6. Stereograms showing fault kinematic results for all oblique-slip ( $A$, population $C$ ) and normal (B, population $D)$ faults with anomalous shortening axes. See figure 4 caption for explanation. 
is $221^{\circ} / 23^{\circ}$. Extension axes plunge moderately toward the east and have an average orientation of $118^{\circ} / 28^{\circ}$. Error margins for Bingham axial distribution statistics were not calculated for this population due to the low number of faults $(\mathrm{n}=12)$.

Only five normal faults were discovered in this study and they form a poorly defined population (D, fig. 6B). Although shortening axes cluster and plunge steeply $\left(133^{\circ} / 78^{\circ}\right)$, the attitudes of fault planes, striations, and extension axes are not consistent within the population. On this basis it is inferred that the normal faults likely reflect local strain patterns rather than regionally significant deformation. For this reason, normal faults are not discussed further.

\section{Calcite Veins}

Tensile (mode-I), calcite-filled fractures (veins) are present in the study area and commonly are spatially associated with faults and used as kinematic indicators (for example, fig. 3C). The total population of veins $(\mathrm{n}=35)$ can be divided into three subsets on the basis of natural breaks in their strike (fig. 7A). One subset $(\mathrm{n}=11)$ consists of steeply to moderately dipping, northwest-striking veins that have a mean strike of $312^{\circ}$. A second subset contains steeply dipping, east-striking veins that have a mean strike of $91^{\circ}$. The third subset contains shallowly to steeply dipping veins that strike northeast and have a mean strike of $38^{\circ}$ (figs. 7B-D).

Piston experiments have demonstrated that tensile veins (mode-I fractures) open in the direction of the minimum compressive stress (see review by Hancock, 1985, and references therein). Thus we deduce that if poles to a subset of tensile veins are subparallel to the extension axes from a particular group of faults then they should approximate the orientation of the minimum compressive stress associated with that group of faults. Poles to the subset of veins that strike northwest are subparallel to the extension axes from population A (fig. 7E). Furthermore, the mean strike of this subset of veins is $13^{\circ}$ from the trend of mean shortening axis of population $\mathrm{A}$, indicating a good geometric correlation between the veins and faults (figs. 7B, E). Poles to the subset of veins that strike east are subparallel to extension axes from population B. In this subset, the mean strike of the veins $\left(091^{\circ}\right)$ plots within the 95 percent confidence interval around the mean shortening axis for population B (figs. 7C, F). Finally, veins that strike northeast have poles that are mostly subparallel to the extension axes of population C. Poles to veins in this subset that are not subparallel to the extension axes (that is, trend northwest, or plunge too steeply or shallowly southeast) still plot within or close to the shortening dihedra for this set of faults (fig. 7G). The mean strike of the veins is within $3^{\circ}$ of the trend of shortening axis of population $\mathrm{C}$ that was determined by linked Bingham statistics (figs. 7D, G). In all three cases, subsets of tensile veins show reasonably good geometric correlation with the respective subsets of faults in the study area and support our interpretation that the faults form three kinematically distinct populations (excluding the subset of normal faults).

\section{SPATIAL DISTRIBUTION OF DEFORMATION}

To qualitatively describe the spatial distribution of deformation for each of the dominant fault sets, fault plane solutions were plotted on the geologic map in their sampling localities. Figure 8A shows the distribution of all faults from population A; figure $8 \mathrm{~B}$ shows those from population B. The small populations of normal faults (D) and faults with southwest-trending shortening axes (C) were not plotted because they only occur in a few locations and do not form a distinct spatial pattern. The Bruin Bay fault segment does not crop out in the study area and, as a result, it is not part of this dataset. Fault kinematic data were not collected from the southeast part of the map area because the authors did not visit those localities during the 2013 field campaign.

It is evident from the map patterns that faults from both populations are distributed throughout the study area and thus exhibit a degree of spatial kinematic homogeneity within each population; however, the bulk deformation is altogether kinematically heterogeneous because faults from both populations occur everywhere in the study area (fig. 8). Thus the data require a mechanism for kinematic heterogeneity, such as triaxial deformation, mechanical anisotropy or strain compatibility constraints, and/or multiple deformations. Despite first-order similarities in the spatial distribution of each fault population a few important distinctions can be made. Minor faults that occur within and in close proximity to the north-northeasttrending fault zone that separates Triassic marble (Trm) from the lower member of the Talkeetna Formation (Jtkl) in the northwest part of the map area (location X in fig. 8) most commonly belong to population B. This indicates that the fault zone records dominantly right-lateral slip that is compatible with the northeast-striking faults in the population. Similarly, minor faults that occupy the northeast-striking contact between the upper and lower members of the Talkeetna Formation (Jtku and Jtkl, respectively) also belong to population B (location Y in fig. 8). In contrast, minor faults that occur along an east-striking fault that cross-cuts the former contact belong to the population with southeast-trending shortening axes (location $\mathrm{Z}$ in fig. 8), suggesting that the latter population of faults (southeast-trending shortening) is younger than the former (east-trending shortening). Minor faults that occur along the trace of the Bruin Bay and Fitz Creek fault segments are dominantly reverse faults that dip southeast, have orientations that are antithetic to the regional structures and belong to population A (southeast-trending shortening); however, faults from population B (east-trending shortening) also occur 


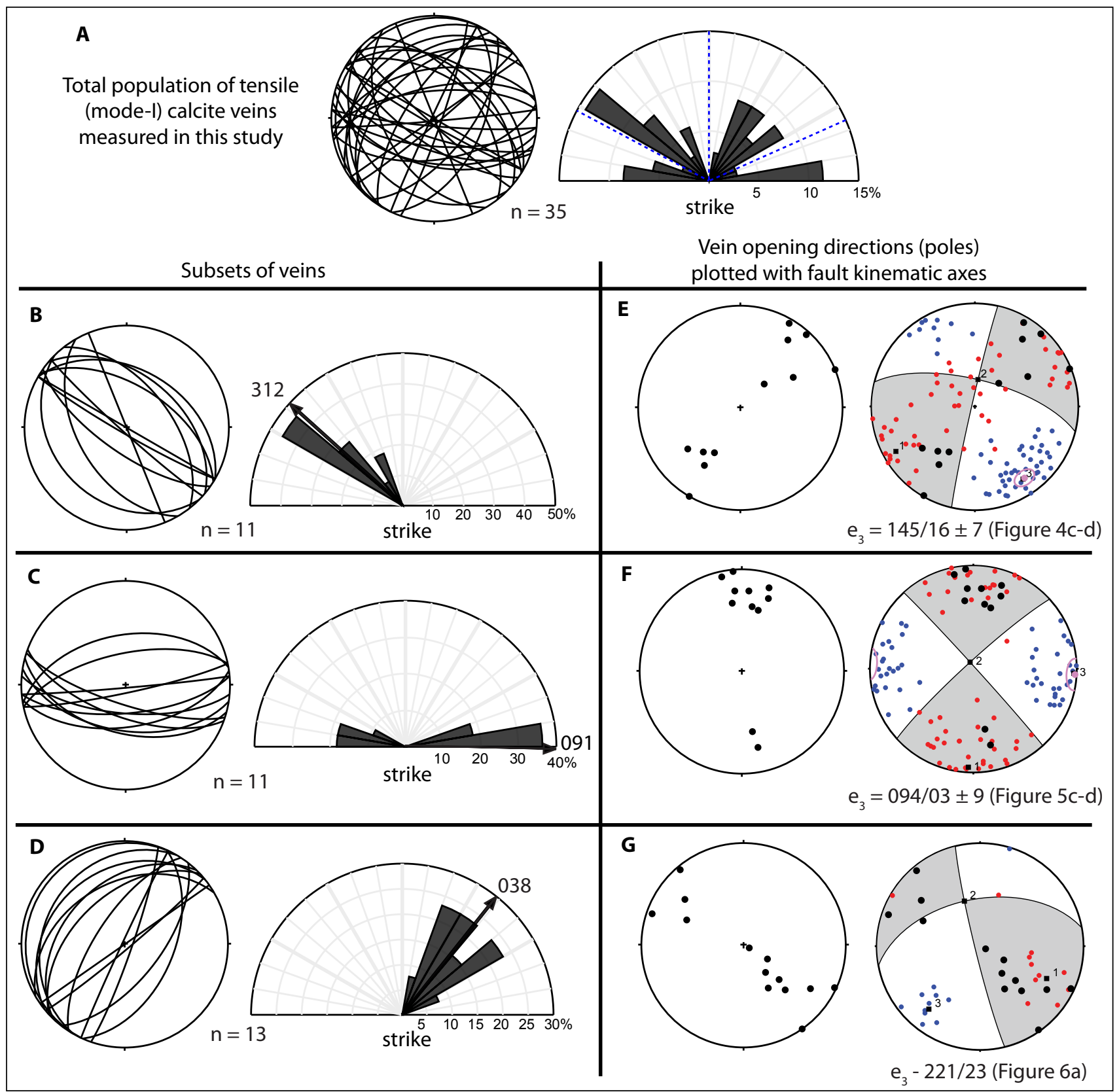

Figure 7. A. Stereogram (left) and rose diagram (right) showing attitudes and strike distributions, respectively, of the total population of veins in this study. Blue dashed lines on the rose diagram indicate natural breaks in strike. B-D. Stereogram (left) and rose diagram showing strike (right) of subsets of veins delineated from A. E-G. Stereograms showing poles to subsets of veins in B-D, respectively (left), and poles to veins plotted with fault kinematic axes (right) from figures 4C-D, 5C-D, and 6A, respectively.

along the Bruin Bay and Fitz Creek fault segments, although they are less common. The map distribution of faults clearly documents the occurrence of faults from each of the dominant kinematically unique subsets along all of the major structures in the study area, indicating bulk kinematic heterogeneity (discussed below).

\section{KINEMATIC HETEROGENEITY TEST}

Bulk kinematic heterogeneity in the map area that is suggested by the spatial distribution of deformation, as discussed in the previous section, is also indicated by multimodal distributions of fault kinematic axes from the two dominant populations ( $\mathrm{A}$ and B, $\mathrm{n}=106$; figs. 9A, B). Shortening axes form a bimodal distribution near the primitive circle with maxima that trend southeast and east and reflect faults from populations A and B, respectively (fig. 9A). Extension axes more clearly 


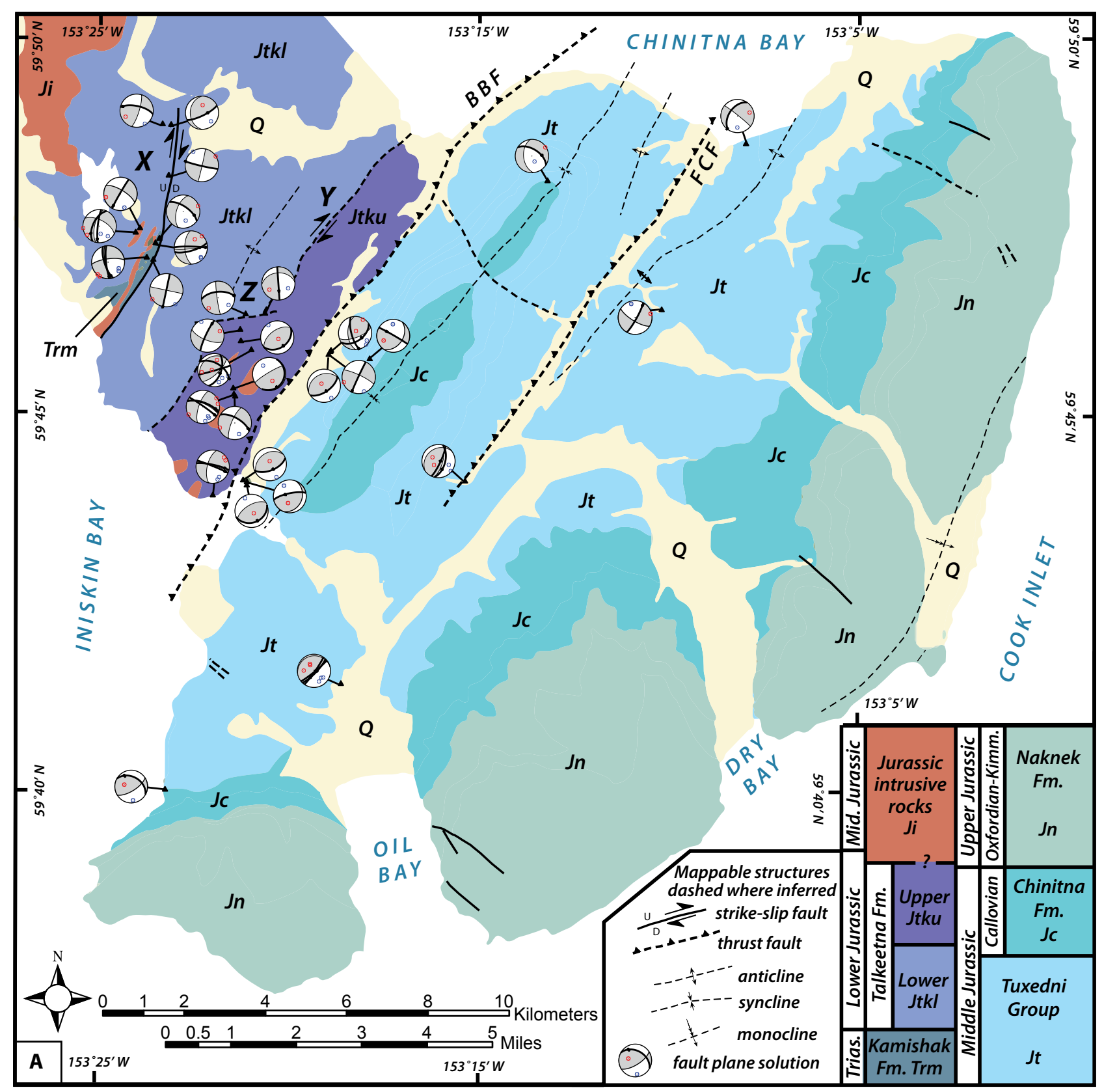

Figure 8A. Simplified geologic map of the Iniskin Peninsula (see fig. 2 for explanation) showing spatial distribution of faults from Population A. Locations $\mathrm{X}, \mathrm{Y}$, and $\mathrm{Z}$ referred to in text are shown.

show a bimodal distribution of shallowly plunging northeast- and north-trending maxima that also reflect populations A and $\mathrm{B}$, respectively. The steeply-plunging extension axes that form an additional submaxima near the center record the reverse faults from population A (fig. 4A). In both cases, kinematic axes form statistically distinct maxima to a Kamb contour interval (Kamb, 1959) of at least 3 sigma (figs. 9A, B), thus supporting our delineation of separate fault populations on the basis of orientation and sense of slip. Moreover, it is evident from the map patterns that most major faults in the study area preserve evidence of both deformations (fig. 8). Kinematic heterogeneity can occur for several reasons, including triaxial deformation, anisotropy reactivation, strain compatibility, and/or multiple deformations. In the following section we test each of these mechanisms to determine the cause and geologic significance of fault kinematic heterogeneity on the Iniskin Peninsula (see discussion in Marrett and Allmendinger, 1990).

Triaxial deformation produces a set of four faults that are in orthorhombic symmetry (Reches, 1983). Poles to faults in this study only form two maxima and they do not have orthorhombic symmetry (fig. 9C), thus precluding triaxial deformation as a likely mechanism. 


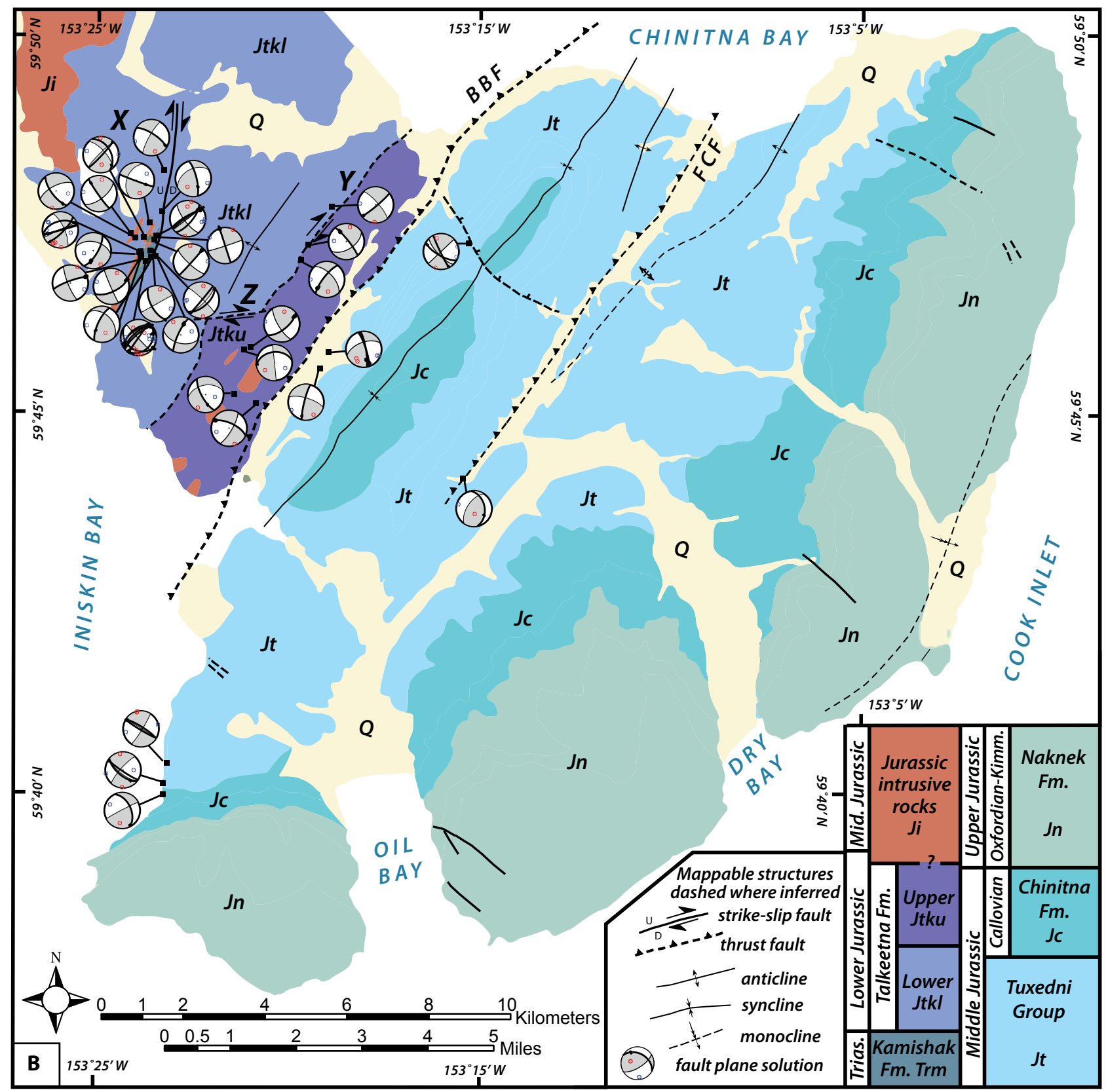

Figure 8B. Simplified geologic map of the Iniskin Peninsula (see fig. 2 for explanation) showing spatial distribution of faults from Population B. Locations $\mathrm{X}, \mathrm{Y}$, and Z referred to in text are shown.

Anisotropy reactivation occurs when fault planes form parallel to the orientation of a pre-existing mechanical layering. In this study, an obvious mechanical layering strikes northeast and is defined by the contacts and bedding layers within folded Jurassic stratigraphy (fig. 2). Both populations of faults have significant subsets of fault planes that strike northeast (figs. 4, 5, and 9C), suggesting that anisotropy reactivation at least partly controlled the orientation of the faults. However, northeast-striking faults from population A include left-lateral and reverse faults (figs. 4A, B) whereas those from population B include only right-lateral faults (fig. 5B), indicating that anisotropy reactivation alone cannot entirely account for kinematic heterogeneity in the study area because faults of similar orientation have opposite senses of slip. This is consistent with the existence of a second population of faults that strike northwest oblique to the structural trend of the map area and thus are also not controlled by mechanical anisotropy.

Strain compatibility requires that two coeval sets of cross-cutting faults with different orientations slip parallel to their line of intersection, otherwise new structures must form to accommodate deformation. Strain compatibility may occur in population A because striations from reverse and northwest-striking right-lateral faults are subparallel to the intersections of 
these two sets of fault planes (figs. 4A-C). However, strain compatibility constraints did not affect north-northeast-striking left-lateral faults from population A, nor did it control any of the faults from population B. On this basis, we infer that the bulk kinematic heterogeneity of the study area generally does not reflect strain compatibility constraints.

Multiple deformations can produce kinematic heterogeneity and/or reactivate faults in a population in response to separate tectonic events. Faults that are reactivated should have multiple sets of slip lineations with varying orientations and kinematics. Northeast-striking faults from populations A and B collectively contain both shallowly- and steeply-plunging striations. This indicates that northeast-striking faults accommodated both strike-slip and dip-slip motion and suggests that fault reactivation occurred (figs. 4A, B). Additionally, northeast-striking faults from population B record right slip (fig. 5B) whereas those in population A record left slip (fig. 4B). Similarly, northwest-striking faults from populations A and B show opposite senses of slip (right and left slip; figs. 4B and 5B, respectively). Altogether, faults from both populations

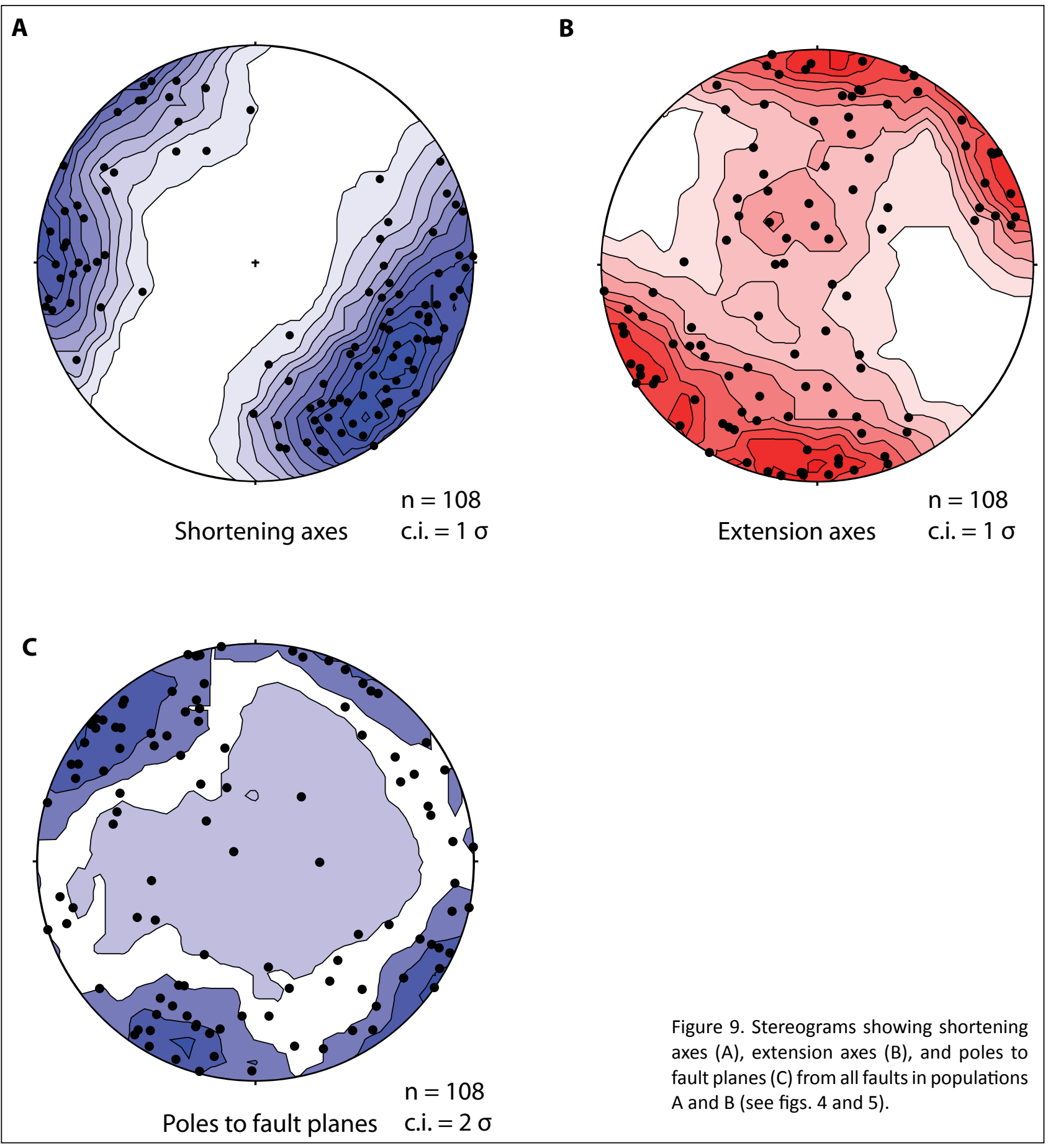


indicate multiple deformations and fault reactivation because subparallel fault segments have varying slip directions and fault kinematics.

Independent evidence of multiple deformations includes systematic cross-cutting relationships or timing constraints on each deformation. On the Iniskin Peninsula, outcrop-scale cross-cutting relationships between the fault sets were commonly ambiguous, owing to the discontinuous nature of outcrop in the study area and small length and displacement scales of the minor fault surfaces that were measured. However, figure 8 clearly indicates that both populations of faults are present throughout the study area and that faults from both populations are preserved along most of the major structures, suggesting fault reactivation. Furthermore, at location $\mathrm{Z}$ (fig. 8A) an east-striking fault segment that contains minor faults from population A cross-cuts a northeast-trending contact that preserves minor faults from population B (location Y in fig. 8B), suggesting Population A faults are younger. In addition to multiple deformations and fault reactivation, anisotropy reactivation also influenced the orientations of faults from both populations. Together, both mechanisms can accommodate the observed heterogeneous fault kinematics.

\section{PRELIMINARY CONCLUSIONS AND ONGOING WORK}

Results from this study indicate that most of the faults observed and measured $(\mathrm{n}=106,86$ percent) on the Iniskin Peninsula can be divided into two fault populations with statistically distinct kinematic histories. Faults from the first set include northeast-striking reverse faults, north-northeast-striking left-lateral strike-slip faults and west-northwest-striking right-lateral faults that altogether record southeast-trending shortening (Population $\mathrm{A}=56$ ). A second population of faults includes northeast- and northwest-striking right- and left-lateral strike-slip faults, respectively, that record east-trending shortening (Population $\mathrm{B}=52$ ). Two small populations of oblique-slip (Population $\mathrm{C}=12$ ) and normal faults (Population $\mathrm{D}=5$ ) also are present but are too few to interpret their regional geologic significance. Three subsets of tensile calcite-filled veins occur and support the delineation of the fault populations. Analysis of fault slip data and spatial distribution of the two dominant fault populations ( $\mathrm{A}$ and $\mathrm{B}$ ) indicates that the data probably reflect two deformations and suggests that fault reactivation likely occurred along all of the major structures that define the Bruin Bay fault system near the Iniskin Peninsula.

We propose several geologic mechanisms that may have contributed to the heterogeneous slip history of faults in the study area, including oroclinal bending of the Alaska Peninsula, bulk noncoaxial deformation in the Bruin Bay fault system, and/ or a spatially transient state of stress in the Cook Inlet region during the Cenozoic. We suggest that the heterogeneous slip history of faults in the study area may reflect oroclinal bending of the Alaska Peninsula that resulted in a temporally variable convergence direction between the North American and the Pacific, Yakatut, Kula, and Farallon plates and the continental margin of North America since the Jurassic. The mean shortening axis for population B is $52^{\circ} \pm 8^{\circ}$ counterclockwise (ccw) from that of population $\mathrm{A}$, which is consistent in magnitude with estimates of Paleogene vertical axis rotation of the Alaska Peninsula near Lake Clark that were determined from paleomagnetic studies $\left(55^{\circ} \pm 28^{\circ} \mathrm{ccw}\right.$, Coe and others, 1989). Ongoing work in 2014-2015 will attempt to constrain relative and/or absolute timing of the two dominant sets of faults. If results show that population B is older than A, then we postulate that population B reflects an earlier phase of deformation in the Bruin Bay fault system that rotated counterclockwise with the Alaska Peninsula during the Paleogene and that population A reflects post-Paleogene deformation. This hypothesis is supported by the observation that the mean shortening axis in population A (southeast-trending) is subparallel to modern convergence directions between North America and the Yakatut $\left(\mathrm{N} 35^{\circ} \mathrm{W}\right)$ and Pacific $\left(\mathrm{N} 17^{\circ} \mathrm{W}\right)$ plates (Fletcher and Freymueller, 2003). If relative timing relationships between the two sets of faults are ambiguous or mutually cross-cutting, and/or absolute timing constraints are indeterminate, then we suggest that heterogeneous fault kinematics on the Iniskin Peninsula may reflect bulk noncoaxial deformation in the Bruin Bay fault system, and/or a spatially transient state of stress in the Cook Inlet region during the Cenozoic. Ongoing work in 2014-2015 will include important visits to well exposed segments of the Bruin Bay fault (see Gillis and others, 2013, for an overview), a study of conjugate fracture sets that occur throughout the study area to determine their relationship to regional structures and approximate paleostress orientations, and expanding the map area to include an additional $335 \mathrm{~km}^{2}$ northeast of the Iniskin Peninsula. New data anticipated to be collected in 2014-2015 will help determine the regional tectonic significance of the Bruin Bay fault system and will be published in a more complete report the following year.

\section{ACKNOWLEDGMENTS}

Mapping in 2013 was supported by the U. S. Geological Survey, National Cooperative Geologic Mapping Program under STATEMAP award number G13AC00157. We thank CIRI and the Seldovia Native Association, Tyonek Native Corporation, Ninilchik Native Association, Salamatof Native Association, Knik Tribal Council, and Chickaloon Village as well as Lake Clark National Park for land access permits. Bear Mountain Lodge provided excellent accommodations and logistical support during the field season. We thank our helicopter pilot, Roger, and Pathfinder Aviation for safe transportation during the field season. James Jones provided a constructive review that improved this paper. 


\section{REFERENCES}

Allmendinger, R.W., Cardozo, N.C., and Fisher, D., 2012, Structural geology algorithms-Vectors and tensors in structural geology: Cambridge, England, Cambridge University Press, 302 p.

Allmendinger, R.W., Cardozo, N.C., and Fisher, D., 2013, Structural geology algorithms - Vectors and tensors: Cambridge, England, Cambridge University Press, 289 p.

Cardozo, N.C., and Allmendinger, R.W., 2013, Spherical projections with OSXStereonet: Computers \& Geosciences, v. 51, no. 0, p. 193-205. doi:10.1016/j.cageo.2012.07.021

Coe, R.S., Globerman, B.R., and Thrupp, G.A., 1989, Rotation of central and southern Alaska in the early TertiaryOroclinal bending by megakinking?, in Kissel, C., and Laj, C., eds., Paleomagnetic Rotations and Continental Deformation: Netherlands, Kluwer Academic Publishers, p. 327-342.

Detterman, R.L., and Hartsock, J.K., 1966, Geology of the Iniskin-Tuxedni region, Alaska: U.S. Geological Survey Professional Paper 512, 78 p., 6 sheets, scale 1:63,360. http://www.dggs.alaska.gov/pubs/id/3873

Detterman, R.L., and Reed, B.L., 1980, Stratigraphy, structure, and economic geology of the Iliamna Quadrangle, Alaska: U.S. Geological Survey Bulletin 1368-B, p. B1-B86, 1 sheet, scale 1:250,000. http://www.dggs.alaska.gov/pubs/id/3682

Fisher, M.A., and Magoon, L.B., 1977, Geologic framework of lower Cook Inlet, Alaska: U.S. Geological Survey OpenFile Report 77-136, $73 \mathrm{p}$.

Fletcher, H.J., and Freymueller, J.T., 2003, New constraints on the motion of the Fairweather fault, Alaska, from GPS observations: Geophysical Research Letters, v. 30, no. 3, p. 1,139-1,142. doi:10.1029/2002GL016476

Gillis, R.J., Swenson, R.F., Wartes, M.A., and Frohman, R.A., 2013, Reconnaissance investigations of the Bruin Bay fault system along the western margin of lower Cook Inlet and upper Alaska Peninsula, in Gillis, R.J., ed., Overview of 2012 field studies - Upper Alaska Peninsula and west side of lower Cook Inlet, Alaska: Alaska Division of Geological \& Geophysical Surveys Preliminary Interpretive Report 2013-1G, p. 33-37. doi:10.14509/24850

Gillis, R.J., Wartes, M.A., Herriott, T.M., Bull, K.F., Decker, P.L., and Betka, P.M., 2014, Overview of new 1:63,360-scale geologic mapping of the Iniskin Peninsula, lower Cook Inlet, Alaska, in Gillis, R.J., Cook Inlet program 2013 field studies - Observations and preliminary interpretations from new 1:63,360-scale geologic mapping of the Iniskin Peninsula, lower Cook Inlet, Alaska: Alaska Division of Geological \& Geophysical Surveys Preliminary Interpretive Report 2014-2-1, p. 3-6. doi:10.14509/27306

Hancock, P.L., 1985, Brittle microtectonics—Principles and practice: Journal of Structural Geology, v. 7, no. 3-4, p. 437-457. doi:10.1016/0191-8141(85)90048-3

Kamb, W.B., 1959, Petrofabric observations from Blue Glacier, Washington, in relation to theory and experiment: Journal of Geophysical Research, v. 64, p. 1,908-1,909.

LePain, D.L., Stanley, R.G., Gillis, R.J., Helmold, K.P., Peterson, C.S., and Wartes, M.A., 2011, Deposition of Middle Jurassic Tuxedni Group, lower Cook Inlet, Alaska-Initial exhumation of an Early Jurassic island arc and incipient motion on the Bruin Bay fault zone [abs.]: American Association of Petroleum Geologists, Pacific Section Annual Meeting, p. 71. http://www.searchanddiscovery.com/abstracts/pdf/2011/pacific/abstracts/ndx_le.pdf

Marrett, R.A., and Allmendinger, R.W., 1990, Kinematic analysis of fault-slip data: Journal of Structural Geology, v. 12, p. 973-986.

1992, Amount of extension on "small" faults -An example from the Viking graben: Geology, v. 20, p. 47-50.

Petit, J.P., 1987, Criteria for the sense of movement on fault surfaces in brittle rocks: Journal of Structural Geology, v. 9, no. 5-6, p. 597-608.

Reches, Ze'ev, 1983, Faulting of rocks in three-dimensional strain fields-II, Theoretical analysis: Tectonophysics, v. 95, no. 1-2, p. 133-156.

Trop, J.M., Szuch, D.A., Rioux, M., and Blodgett, R.B., 2005, Sedimentology and provenance of the Upper Jurassic Naknek Formation, Talkeetna Mountains, Alaska-Bearings on the accretionary tectonic history of the Wrangellia composite terrane: Geological Society of America Bulletin, v. 117, no. 5-6, p. 570-588.

Turcotte, D.L., 1986, A fractal model for crustal deformation: Tectonophysics, v. 132, no. 1-3, p. 261-269.

Wartes, M.A., Herriott, T.M., Helmold, K.P., and Gillis, R.J., 2013, Preliminary stratigraphic interpretation of the Naknek Formation-Evidence for Late Jurassic activity on the Bruin Bay fault, Iniskin Peninsula, lower Cook Inlet, in Gillis, R.J., ed., Overview of 2012 field studies - Upper Alaska Peninsula and west side of lower Cook Inlet, Alaska: Alaska Division of Geological \& Geophysical Surveys Preliminary Interpretive Report 2013-1H, p. 39-46. doi:10.14509/24851

Winkler, G.R., MacKevett, E.M., Jr., Plafker, George, Richter, D.H., Rosenkrans, D.S., and Schmoll, H.R., 2000, A geologic guide to Wrangell-Saint Elias National Park and Preserve, Alaska-A tectonic collage of northbound terranes: U.S. Geological Survey Professional Paper 1616, 166 p. 